\title{
SEROPREVALENSI BRUCELLOSIS DAN TINGKAT GANGGUAN REPRODUKSI PADA SAPI PERAH DI KOTA BATU
}

\section{Seroprevalence of Bovine Brucellosis and Reproduction Problems Rate in Dairy Cattle of Batu Regency}

\author{
Ani Setianingrum ${ }^{1}$, Mira Fatmawati ${ }^{1}$, Aulia Firmawati ${ }^{2}$, Dahliatul Qosimah ${ }^{3}$, Fidi Nur Aini \\ E P Dameanti ${ }^{3}$, Wahyu Islami ${ }^{4}$, Utami Kurniawati ${ }^{4}$, dan Lisa D Andriyani ${ }^{4}$ \\ ${ }^{1}$ Laboratorium Kesehatan Masyarakat Veteriner, Fakultas Kedokteran Hewan Universitas \\ Brawijaya, Malang \\ ${ }^{2}$ Laboratorium Reproduksi Veteriner, Fakultas Kedokteran Hewan Universitas Brawijaya, Malang \\ ${ }^{3}$ Laboratorium Mikrobiologi Veteriner, Fakultas Kedokteran Hewan Universittas Brawijaya, \\ Malang \\ ${ }^{4}$ Dinas Pertanian Kota Batu, Malang \\ ${ }^{*}$ Email: ani.setia@ub.ac.id
}

\begin{abstract}
INTISARI
Penelitian bertujuan untuk mengukur tingkat kejadian brucellosis pada ternak sapi perah di Kota Batu berdasarkan uji serologis (seroprevalensi) serta mengetahui hubungan antara kejadian brucellosis dengan gangguan reproduksi. Penelitian epidemiologis lintas seksional dilakukan untuk mengetahui prevalensi brucellosis pada sapi perah. Sampel serum diperoleh dari 130 ekor sapi perah umur di atas 6 bulan, data gangguan reproduksi menggunakan kuesioner pada 21 peternak. Pengujian serologis menggunakan uji Rose Bengal Test (RBT) dan dilanjutkan uji Complement Fixation Test (CFT). Analisis data menggunakan uji statistik korelasi Pearson's Chi-Square. Seroprevalensi brucellosis di Kota Batu adalah 0,7\%. Prevalensi gangguan reproduksi pada sapi perah adalah $29,2 \%$ yang terdiri atas abortus $8,5 \%$ dan kawin berulang $20,8 \%$. Terdapat korelasi antara brucellosis dengan kejadian abortus $\left(\chi^{2}=10,90 ; \mathrm{P}<0,05\right)$ dan korelasi antara kejadian abortus dengan umur sapi lebih dari 3 tahun $\left(\chi^{2}=5,35 ; P<0,05\right)$. Kesimpulan dari penelitian ini menunjukkan bahwa prevalensi brucellosis di Kota Batu yaitu rendah $(<2 \%)$. Hasil penelitian ini dapat digunakan sebagai dasar pelaksanaan program vaksinasi dan pemberantasan brucellosis di Jawa Timur.
\end{abstract}

Kata kunci: Brucellosis, Reproduksi, Sapi Perah, Seroprevalensi

\begin{abstract}
This study aimed to measure the incidence rate of brucellosis in dairy cattle at Batu City based on serological tests (seroprevalence) and to determine the relationship between the incidence of brucellosis and reproductive disorders. Cross-sectional epidemiological research was conducted to determine the prevalence of brucellosis in dairy cows. Serum samples were obtained from 130 dairy cows over 6 months of age, reproductive disorders data using a questionnaire on 21 farmers. Serological testing used the Rose Bengal Test (RBT) and continued with the Complement Fixation Test (CFT). The data analysis used Pearson's Chi-Square correlation statistical test. The seroprevalence of brucellosis at Batu City was $0.7 \%$. The prevalence of reproductive disorders in dairy cows was $29.2 \%$ consisted of $8.5 \%$ abortion and 20.8\% repeated mating. There was a correlation between brucellosis and the incidence of abortion $\left(\chi^{2}=10.90 ; P<0.05\right)$ and a correlation between the incidence of abortion and the age more than 3 years $\left(\chi^{2}=5.35 ; P<0.05\right)$. The conclusion of this study showed that the prevalence of brucellosis at Batu city was low $(<2 \%)$. The results of this study could be used as the basis for implementing a vaccination program and eradicating brucellosis at East Java.
\end{abstract}

Key words: Brucellosis, Reproduction, Dairy cattle, Seroprevalence 


\section{PENDAHULUAN}

Brucellosis pada sapi perah disebabkan oleh bakteri Brucella abortus. Pada umumnya brucellosis menginfeksi sapi, kerbau, kambing, domba, dan babi. Penyakit ini juga dapat menyerang berbagai jenis hewan lainnya dan ditularkan ke manusia atau bersifat zoonosis (Moreno, 2014). Pada hewan betina, penyakit ini dicirikan oleh aborsi dan retensi plasenta, sedangkan pada jantan dapat menyebabkan orchitis dan infeksi kelenjar aksesori (Manish et al., 2016). Brucellosis pada manusia dikenal sebagai undulant fever karena menyebabkan demam yang undulans atau naik-turun.

Brucellosis pertama kali dilaporkan di Indonesia pada tahun 1953. Sejak itu reaktor brucellosis telah ditemukan secara luas di pulau-pulau besar di Indonesia, seperti Sumatera, Jawa, Kalimantan, Sulawesi, dan Pulau Timor, kecuali Bali (DIRKESWAN, 2015). Provinsi Jawa Timur merupakan kantong ternak nasional dengan populasi ternak sapi potong maupun sapi perah terbanyak di Indonesia. Kota Batu selain dikenal sebagai kota wisata, juga merupakan salah satu lokasi usaha peternakan sapi perah. Perkembangan peternakan ditentukan oleh berbagai faktor antara lain kualitas bibit, keberhasilan reproduksi, kesehatan dan manajemen pemeliharaan.

Infeksi Brucella abortus dapat menyebabkan kerugian pada peternakan sapi perah maupun sapi potong. Kerugian akibat penyakit ini diperkirakan mencapai Rp138,5 milyar per tahun yang disebabkan karena kematian ternak. Selain itu kerugian juga disebabkan karena penurunan produksi dan produktivitas akibat infertilitas serta gangguan reproduksi (DIRKESWAN, 2015). Sebagai daerah kantung ternak, kejadian gangguan reproduksi pada sapi perah di Jawa Timur masih tinggi dan prevalensi brucellosis di Jawa Timur adalah di atas 2\% (Samkhan et al, 2015). Program surveilance brucellosis merupakan program pemerintah sebagai upaya pembebasan brucellosis tahun 2020 .
Pengujian Rose Bengal Test (RBT) dan Complement Fixation Test (CFT) merupakan uji standar yang diterapkan oleh OIE. Uji RBT berfungsi sebagai uji skrining awal. Reaktor positif RBT selanjutnya akan dites kembali dengan CFT sebagai uji yang menentukan brucellosis (Nielsen and Ewalt, 2004).

Tujuan dari penelitian ini adalah untuk mengukur tingkat kejadian brucellosis pada ternak sapi perah di Kota Batu berdasarkan uji serologis (seroprevalensi) serta mengetahui hubungan antara kejadian brucellosis dengan gangguan reproduksi pada sapi perah.

\section{MATERI DAN METODE}

Penelitian lintas seksional dilakukan pada bulan Juli sampai dengan Agustus 2019 di Kota Batu, Malang dengan responden sebanyak 21 peternak sapi perah rakyat dengan sistem pemeliharaan intensif. Data kejadian gangguan reproduksi pada sapi perah berupa sejarah abortus dan kawin berulang berdasar jumlah service per conception (S/C).

\section{Lokasi Penelitian}

Pengambilan sampel serum untuk uji serologis dan data kuesioner dilakukan di peternakan sapi perah daerah Kota Batu yang mencakup Kecamatan Junrejo, Kecamatan Batu, dan Kecamatan Bumiaji. Pengujian serologis RBT dilakukan di Laboratorium Mikrobiologi Fakultas Kedokteran Hewan Universitas Brawijaya Malang dan pengujian CFT dilakukan di Balai Veteriner Lampung.

\section{Metode Pengambilan Sampel}

Metode pemilihan sampel menggunakan simple random sampling. Jumlah sampel untuk tiap kecamatan di Kota Batu ditentukan berdasarkan proporsi dari populasi di tiap kecamatan. Data jumlah populasi yang digunakan adalah data populasi sapi perah dari Badan Pusat Statistik Kota Batu tahun 2018 sebanyak 11.611 ekor, tingkat 
kepercayaan sampling 95\% dengan galat 10\%. Perhitungan jumlah sampel adalah sebagai berikut:

$$
\begin{aligned}
& \mathrm{n}=\frac{\mathrm{N}}{\mathrm{N} \cdot \mathrm{d}^{2}+1} \\
& \mathrm{n}=\frac{11611}{11611 \cdot 0,1^{2}+1} \\
& \mathrm{n}=99,15=100 \text { sampel }
\end{aligned}
$$

Populasi sapi perah untuk kecamatan Batu adalah 5.084 ekor, Kecamatan Junrejo sebanyak 2.843 ekor dan Kecamatan Bumiaji sebanyak 2.843 ekor. Jumlah sampel untuk Kecamatan Batu adalah 44 sampel, Kecamatan Junrejo sebanyak 26 sampel dan Kecamatan Bumiaji sebanyak 32 sampel Penelitian ini menggunakan 130 sampel serum. Sampel darah diambil melalui vena jugularis pada tiap ekor sapi perah dan disimpan pada tabung vacutainer untuk mendapatkan serum. Sampel serum kemudian disimpan pada suhu $-20{ }^{\circ} \mathrm{C}$ untuk pengujian selanjutnya.

\section{Kuisioner}

Survei dilakukan dengan menggunakan kuesioner pada 20 peternak sapi perah di 3 kecamatan yang ada di Kota Batu. Survei dilakukan untuk mengetahui data kejadian gangguan reproduksi pada ternak antara lain abortus dan jumlah S/C yang mungkin berhubungan dengan kejadian brucellosis. Data lain yang diambil adalah umur ternak, breed, dan karakteristik peternak.

\section{Pengujian Serologis}

Uji serologis Rose Bengal Test (RBT) dengan menggunakan antigen RBT produksi Pusvetma yang digunakan sebagai uji screening akan adanya Brucella aglutinin pada sampel serum. Metode uji RBT seperti yang digunakan seperti rekomendasi OIE (Nielsen and Ewalt, 2004). Cara kerja uji RBT adalah sebagai berikut: sebanyak $0,03 \mathrm{ml}$ serum diambil menggunakan mikropipet kemudian diletakkan pada slide kaca. Antigen RBT sebanyak $0,03 \mathrm{ml}$ dicampurkan secara merata dengan sampel serum kemudian diamati akan ada tidaknya aglutinasi.

Interpretasi hasil uji RBT berdasarkan Neilsen and Duncan (1990) sebagai N (0), +, ,+++++ , sebagai berikut:

$\mathrm{N}=$ tidak ada aglutinasi

$+\quad=$ sangat sedikit/hampir tidak terlihat aglutinasi

$++\quad=$ aglutinasi jelas

$+++=$ terjadi clumping dan cairan jernih yang terpisah

Hasil negatif adalah dari pembacaan tidak terjadi adanya aglutinasi $(\mathrm{N})$, dan hasil positif adalah hasil pembacaan,,++++++ .

Pada penelitian ini semua sampel dengan hasil RBT positif maupun negatif dilakukan pengujian Complement Fixation Test (CFT). Uji RBT dan CFT dilakukan secara pararel untuk meningkatkan peluang terdeteksinya individu yang terinfeksi (Mujiatun et al., 2016). Prinsip uji CFT adalah antigen brucella berikatan dengan antibody brucella membentuk kompleks imun. Komplemen yang terbentuk tidak dapat melisiskan sel darah merah yang merupakan indikator pada uji CFT. Interpretasi hasil dari uji CFT adalah hasil positif apabila terjadi sedimentasi sel darah merah, dan hasil negatif apabila terjadi hemolisis pada sel darah merah (Nielsen and Ewalt, 2004).

\section{Analisis data}

Point prevalence kejadian brucellosis pada sapi perah berdasarkan hasil CFT positif dari total populasi sampel yang diuji dalam persentase kejadian. Angka prevalensi gangguan reproduksi dihitung dari total populasi sampel. Hubungan antara variabel pada penelitian dihitung menggunakan uji cross tab untuk mengetahui nilai Pearson's chisquare dan risk analysis dengan software SPSS.

\section{HASIL DAN PEMBAHASAN}

\section{Seroprevalensi Brucellosis pada Sapi Perah di Kota Batu}

Dari total 130 sampel serum yang diuji menggunakan uji RBT dan dilanjutkan dengan 
uji CFT, terdapat 1 sampel positif. Berdasarkan hasil ini persentase seropositif brucellosis dari total sampel serum sebesar $0,7 \%$. Data prevalensi brucellosis pada sapi perah disajikan pada Tabel 1 .

Hasil penelitian ini menunjukkan bahwa masih terdapat kasus brucellosis pada sapi perah di Kota Batu. Menurut Roadmap nasional pemberantasan Brucellosis (DIRKESWAN, 2015), Pendekatan zona (zoning approach) didasarkan atas daerah bebas penyakit, daerah tertular ringan $(<2 \%)$, daerah tertular berat $(>2 \%)$, dan daerah tersangka (prevalensi tidak diketahui). Berdasarkan hasil seroprevalensi yang diperoleh dari pengujian RBT dengan konfirmasi CFT positif, maka status brucellosis di kota Batu termasuk pada prevalensi rendah $(<2 \%)$.

Brucellosis terjadi hampir di seluruh dunia, termasuk Indonesia. Penyakit ini dianggap penting dan mempunyai dampak ekonomi pada industri sapi perah dan sapi potong di Indonesia (DIRKESWAN, 2015). Program pemberantasan brucellosis telah dilaksanakan sejak tahun 1996. Jawa Timur masih didominasi oleh kasus gangguan reproduksi dengan rerata kejadian brucellosis tahun 2010 sampai 2014 sebesar 3,1\% sehingga Jawa Timur merupakan prioritas pengendalian dan pemberantasan brucellosis (Samkhan et al., 2015).

Tabel 1. Data populasi dan Seroprevalensi Brucellosis pada Sapi Perah di Kota Batu

\begin{tabular}{lcccccccc}
\hline \multirow{2}{*}{ Lokasi } & Jumlah & \multicolumn{2}{c}{ Umur (tahun) } & S/C & Pernah & RBT & CFT \\
& sampel & $<1$ & $>1-3$ & $>3$ & $>3$ kali & abortus & positif & positif \\
\hline Kec. Bumiaji & 44 & 9 & 25 & 10 & 0 & 2 & 0 & 0 \\
Kec. Junrejo & 30 & 0 & 8 & 22 & 0 & 5 & 0 & 0 \\
Kec. Batu & 56 & 7 & 18 & 31 & 27 & 4 & 1 & 1 \\
\hline Total & 130 & 16 & 51 & 63 & 27 & 11 & 1 & 1 \\
\hline \multicolumn{2}{c}{ Persentase } & $12,3 \%$ & $39,2 \%$ & $48,5 \%$ & $20,8 \%$ & $8,5 \%$ & $0,77 \%$ & $0,77 \%$ \\
\hline
\end{tabular}

Analisis korelasi antara kejadian brucellosis dengan kejadian gangguan reproduksi pada sapi perah pada Tabel 2 menunjukkan tidak terdapat korelasi antara kejadian brucellosis dengan variabel umur sapi dan variabel kawin berulang. Terdapat korelasi yang kuat antara brucellosis dengan sejarah abortus $\left(\chi^{2}=10,90 \mathrm{p}<0,05\right)$ dengan relative risk 1,10 (95\%; CI 0,91-1,33), risiko kejadian abortus meningkat pada sapi yang positif brucellosis.

Brucellosis merupakan salah satu agen penyakit pada sapi perah maupun sapi potong yang dapat menyebabkan abortus dan retensi plasenta (Degefa et al., 2011). Infeksi bakteri Brucella abortus pada sapi perah dapat menyebabkan abortus dan kawin berulang, serta menyebabkan penurunan produksi susu sampai dengan $25 \%$ karena gangguan laktasi (Padaga et al., 2018).

\section{Prevalensi Gangguan Reproduksi pada Sapi Perah}

Angka kejadian gangguan reproduksi pada sapi perah di Kota Batu sebesar 29,2\% (38/130) yang terdiri atas abortus 8,5\% $(11 / 130)$ dan kawin berulang 20,8\% (27/130). Variabel umur dibagi menjadi kategori kurang dari 1 tahun, umur 1 sampai 3 tahun, dan umur diatas 3 tahun. Data populasi tiap kecamatan dan kisaran umur pada sapi perah pada Tabel 1

Analisis korelasi menggunakan Pearson's Chi-square menunjukkan tidak terdapat korelasi antara kejadian abortus terhadap kawin berulang. Terdapat korelasi antara kejadian abortus dengan umur sapi diatas 3 tahun $\left(\chi^{2}=5,35, \mathrm{p}<0,05\right)$ dengan odd ratio 5,42 (CI 95\% 1,12-26,14). Berdasarkan hasil ini, sapi perah yang berumur lebih dari 3 tahun 5 kali lebih berisiko mengalami abortus 
dibandingkan sapi yang lebih muda. Risiko kejadian abortus meningkat sejalan dengan pertambahan umur induk pada saat konsepsi, dan meningkat pada induk sapi dengan sejarah aborsi sebelumnya (Thurmond et al.,
2005). Menurut Padaga et al. (2018) sapi perah dara berumur kurang dari 6 bulan kurang berisiko terhadap infeksi brucella dan sapi betina muda yang terinfeksi Brucella sebelum beranak jarang mengalami abortus.

Tabel 2. Analisis Korelasi dan Kejadian Brucellosis dengan Umur dan Gangguan Reproduksi

\begin{tabular}{lccc}
\hline \multicolumn{1}{c}{ Variabel } & $\chi^{2}$ & $P$ value & Relative Risk $(95 \%$ CI) \\
\hline Umur sapi & & & \\
$<1$ tahun & 0,14 & 0,71 & $0,99(0,97-1,01)$ \\
$1-3$ tahun & 0,65 & 0,42 & $0,98(0,96-1,01)$ \\
$>3$ tahun & 1,07 & 0,30 & $1,02(0,98-1,05)$ \\
\hline S/C $>3$ kali & 0,26 & 0,60 & $0,99(0,97-1,01)$ \\
Sejarah abortus & 10,90 & $0,01^{*}$ & $1,10(0,91-1,33)$ \\
\hline
\end{tabular}

${ }^{*}$ Korelasi signifikan pada $\chi^{2}>3,841(\mathrm{P}<0,05)$

Brucellosis berdasarkan aspek berisiko, pengendalian lalu lintas ternak antar kesehatan masyarakat merupakan penyakit daerah, dan penelusuran asal hewan yang berisiko tinggi terutama pada negaranegara berkembang dimana pengendalian dan pemberantasan penyakit pada ternak masih kurang baik. Kebijakan pemberantasan brucellosis di Indonesia dilakukan melalui pendekatan bertahap yang meliputi kegiatan pengendalian berupa identifikasi dan penyembelihan hewan reaktor yaitu sapi yang positif uji RBT dan CFT dengan pemotongan bersyarat, program vaksinasi pada populasi (DIRKESWAN, 2015).

Kegiatan surveilans aktif dan program vaksinasi dilakukan pada daerah dengan tingkat prevalensi brucellosis diatas $2 \%$, dengan cakupan vaksinasi adalah minimal $80 \%$ dari total populasi (FAO, 2015). Hasil dari penelitian ini diharapkan dapat menjadi bahan pertimbangan untuk program pengendalian dan pemberantasan brucellosis di Kota Batu.

Tabel 3. Analisis korelasi dan Odd ratio sejarah abortus pada sapi perah

\begin{tabular}{|c|c|c|c|}
\hline Variabel & $\chi^{2}$ & Pvalue & Odd Ratio (95\% CI) \\
\hline \multicolumn{4}{|l|}{ Umur sapi } \\
\hline$<1$ tahun & 1,69 & 0,19 & $0,90(0,85-0,96)$ \\
\hline $1-3$ tahun & 2,23 & 0,14 & $0,32(0,66-1,53)$ \\
\hline$>3$ tahun & 5,35 & $0,02^{*}$ & $5,42(1,12-26,14)$ \\
\hline \multicolumn{4}{|l|}{$\mathrm{S} / \mathrm{C}$} \\
\hline >3 kali & 0,05 & 0,83 & $0,84(0,17-4,15)$ \\
\hline
\end{tabular}

${ }^{*}$ Korelasi signifikan pada $\chi^{2}>3,841(\mathrm{P}<0,05)$

\section{KESIMPULAN}

Studi lintas seksional pada peternakan sapi perah rakyat di Kota Batu diperoleh hasil seroprevalensi brucellosis sebesar 0,7\%. Terdapat korelasi antara kejadian brucellosis dengan abortus sapi perah bahwa pada umur lebih dari 3 tahun lebih berisiko mengalami abortus.

\section{UCAPAN TERIMA KASIH}

Penelitian ini merupakan kerja sama antara Fakultas Kedokteran Hewan Universitas Brawijaya dan Dinas Pertanian Kota Batu. Terima kasih pada LPPM Universitas Brawijaya atas dana hibah penelitian, Laboratorium Mikrobiologi Fakultas Kedokteran Hewan Universitas 
Brawijaya dan Balai Veteriner Lampung atas fasilitas yang diberikan.

\section{DAFTAR PUSTAKA}

Degefa, T., A. Duressa, and R. Duguma. 2011. Brucellosis and some reproductive problems of indigenous arsi cattle in selected Arsi zones of Oromia regional state, Ethiopia. Global Veterinaria. $7(1): 45-53$.

Direktorat Jenderal Peternakan dan Kesehatan Hewan (DIRKESWAN). 2015.

Road Map Pengendalian dan Penanggulangan Brucellosis. Direktorat Jenderal Peternakan dan Kesehatan Hewan. Kementrian Pertanian Republik Indonesia. Jakarta.

FAO. 2015. Regional Workshop on Brucellosis Control in Central Asia and Eastern Europe. FAO Animal Production and Health Report No. 8. Rome.

Manish, K., P. Chand, C. Rajesh, R. Teena, and K. Sunil. 2013. Brucellosis: an updated review of the disease. Indian Journal of Animal Sciences. 83(1):3-16.

Moreno, E. 2014. Retrospective and prospective perspectives on zoonotic brucellosis. Frontiers in microbiology. 5: 1-18.

Mujiatun, M., R.D. Soejoedono, E. Sudarnika, dan S.M. Noor. 2016. Deteksi spesies brucella pada kambing di rumah potong hewan Jakarta. Jurnal Sain Veteriner. 34(2):172-181.

Neilsen, K. and J. Duncan. 1990. Animal Brucellosis. $1^{\text {st }}$ ed. CRC Press. Boca Raton

Nielsen, H. and R. Ewalt. 2004. Bovine brucellosis: In manual of standards for diagnostic tests and vaccines. 5th Ed OIE. Paris, France.

Padaga, M.C., A. Setianingrum, dan M. Fatmawati. Penyakit Zoonosa Strategis di Indonesia: Aspek Kesehatan Masyarakat Veteriner. Universitas Brawijaya Press. Malang.

Samkhan., R. Ikaratri, dan M.F. Isnaini. 2015. Rencana Pendahuluan Road Map untuk Pembebasan Brucellosis di Pulau Jawa Tahun 2020. Buletin Laboratorium Veteriner. 15(4):1-9. 